\title{
How are the Principles of Aswaja in the Multifaith School?
}

\author{
Muhammad Sulistiono, Zuhkhriyan Zakaria, Ika Ratih Sulistiani, Lia Nur Atiqoh Bela Dina \\ (e-mail: muhammad.sulistiono@unisma.ac.id) \\ Islamic Elementary School Teaching, Faculty of Islamic Studies, Universitas Islam Malang, Indonesia
}

\begin{abstract}
This article discusses the implementation of the principles of Aswaja in multifaith school Selamat Pagi Indonesia (SMA SPI). In some case related to the differences in religion usually trigger conflict, conflict in the scope of the small and the great scope. This research has used a case study design, which has been conducted from 2016 to 2018. SMA SPI present offers the pattern to soften the conflict that triggered because of religious differences. SMA SPI recruit students from various religions who are then educated so that they have an inclusive attitude. The inclusive attitude itself is the opposite of exclusive. In other words, it means not easily provoked with the issue of religious differences, tribes, races, and others. In order to provide learning about the formation of inclusive attitude, Aswaja principles become the main material in the process of learning in SMA SPI. The principles of Aswaja include at-ta'aruf, at-tawassuth, at-tasamuh, at-ta'awun, and at-tawazun. The implementation of the principles of the Aswaja, there are many interesting experiences experienced by students, mainly in the learning process as it requires social sensitivity and creativity of the students to solve the problems that triggered by religious differences
\end{abstract}

Key words: multifaith school, principles of aswaja, inclusive attitude, religion education

\section{Introduction}

A school is a place for formal learning for the community in Indonesia. Almost all the parents entrust their children at school [1] with the hope that their children are able to draw the science in schools [2]-[4]. Most schools in Indonesia located in a location that consists of the classroom building, offices, laboratories, library and, others. In general, learning activities are limited to the location of schools or school fence [5]. Now, the limited learning activities are at a certain time between hours 07.00 AM-01.30 PM for senior high school level. The policy of using integrated school uniforms has been arranged to start Monday to Saturday, gray and white uniforms become characteristic of upper secondary schools. In general, the school applied in Indonesia tend to be behaviorism [6].

However, in Batu, the city in East Java in Indonesia, a senior high school was established and named Good Morning (Selamat Pagi) Indonesia or commonly called SMA SPI. The appearance of this school looks like a tourist destination from the outside that includes the facilities of tourism place in general such as bus parking area, hotel, theater stages, and 
outbound. Besides that, this school has five places of worship to facilitate students' religious activities, considering their various religious backgrounds. Compared with other schools, this school is variously unique.

SMA SPI was founded by Yulianto Eka Putra, a Chinese descent businessman from Surabaya. Concerning the conflict that has occurred in Indonesia that was influenced by cultural and religious issues, he built the school of SMA SPI. He is well known in all the SMA students from the SPI. If SMA SPI students are asked about their dreamed job, most of them will mention to becoming a Ko Yul (Yulianto Eka Putra founded the call of SMA SPI).

The vision of SMA SPI is forming Indonesians who possess Pancasila soul, become superior, independent, have cultural identity, be aware to environment, and be able to compete in the Global Era. Then, the missions of SMA SPI are 1) Organizing learning based on the faith and obedience (imytaq), with getting prayer together in accordance with the schedule and each religion. 2) increasing the value of humanity, brotherhood, democracy and social justice, with active in following the activities in the hostel. 3)Improving, and academic excellence by optimizing the effectiveness of the learning process both inside and outside the classroom. 4) Enhancing excellence in the field of non-academic with extracurricular activities outside of school hours. 5) The development of science and technology, through the process of technology-based teaching and learning using computer facilities, LCD and internet networks in the process of learning. 6) Investing the soul of entrepreneurship through extracurricular activities. 7) Getting the schools to promote clean and have a sense of love to the environment. 8) Organizing life skills based-learning (life skill) for the next independent generation of through PAKSA assessment method (Pray, Attitude, Knowledge, Skill, Action). 9) Organizing learning that compatible in the global era, with the use of IT based learning media (Information and Technology), and practicing foreign language (English and Chinese).

The name of the- SMA Selamat Pagi Indonesia was attached for the reason that the school students, -even in the middle of the night, when they meet each other, they always greet the good morning. Its philosophy is the students still have the spirit as the spirit in the morning, whenever time despite lunch afternoon even night. SMA SPI was established in 2007. Now, it has the number of students reaching 137. Now, the background of the students in Senior SMA SPI is multi-ethnic and multi-religious, the students stay in the hostel that has been provided by the institution. Besides that, the students do not incur the cost of the school for learning at SMA SPI.

From the above background, it can be concluded that SMA SPI is a school that the students have all kinds of religion that Islam, Christians, Catholics, Hindus, Buddhists, and Confucius faith. In addition to this, the students of SMA SPI consist of various tribes in Indonesia. Description of the uniqueness of SMA SPI above became one argument that management experience, teachers and students become an intention that need to be analyzed more in order to get various life lessons on the implementation of the Aswaja -values in shaping Aswaja inclusive attitude of SMA SPI students. In the study of Aswaja or Aswaja Islamic inclusive, there are the roots of the values that promote inclusive character actualization of multiculturalisme in a society or nation, including at-ta'aruf, at-tawassuth, at-tasamuh, at-ta'awun, and at-tawazun [7]. Now the details of the five roots inclusive is as follows. In previous research on SPI SMA discussed multicultural education [8], religious freedom [9], entrepreneurship [10] fun ecopreneur [11] etc. Aswaja in educational research in the field of multicultural education [12], national character [13], aqeedah [14], radicalism [7], [15], etc. But rarely does it examine the implementation of the principles of Aswaja. 


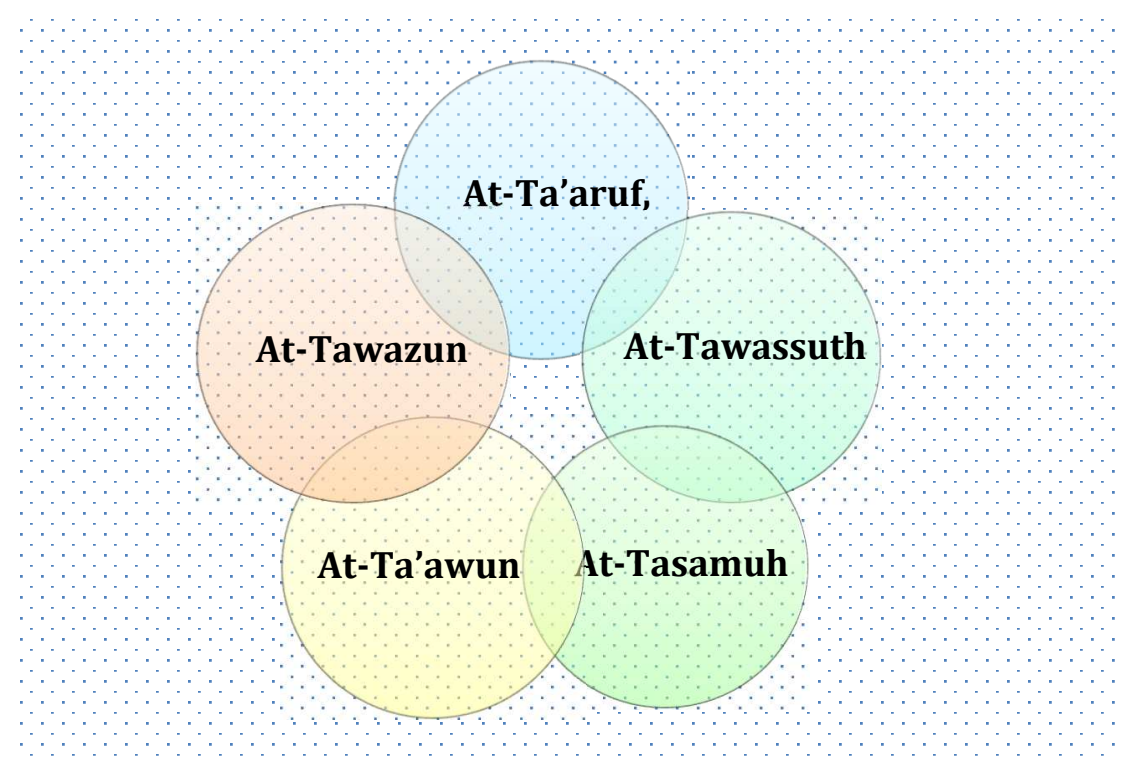

Figure 5. The Principles of Aswaja

\section{At-Ta'aruf}

At-ta'aruf is the gate of the process of interaction between individuals or groups without obstacles difference of skin color, culture, religion or language. Ta'aruf-became posisitive indication and constructively in the plural society to be able to live together with mutual respect and accept the differences between them. Ta'aruf become cultural gate that gives access to the next steps in building the sharing of life with peace through these characters inclusive. In the Qur'an Letter Hujurat verse 13 Allah swt said and gives knowledge to mankind that Allah swt has created man from a single soul and from it $\mathrm{He}$ created the husbands, namely Adam and Hawaa' [16]. Then He made them into peoples. The word

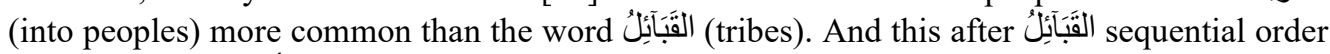
of the other, as الفصائل و العثائر و العمائر و الأفخاذ namely, and others.

So, that is the meaning and the explanation of the letter Hujurat verse 13,from that we can take the conclusion of the verse that God indeed created man with into peoples and tribes so that we can get to know each other and helped each other. The verse also shows the meaning of multicultural society which could not be distinction or diversity among one tribe with the others. All the tribes and all of the nations are the same in any rights. In the verse, Islam recognizes the existence of ethnic and religious differences.

\subsection{At-Tawassuth}

The attitude of tawassuth (moderate) became the identity of Moslems s, as asserted in the Qur'an letter Albaqarah 143. The verse can be understood that I made you (Moslems s) as moderate people/just so that you can become a witness to mankind and the Apostles (Muhammad become a witness for you) [16]. Ibnu Asyur in his interpretaion said that the common understanding of "at-tawassuth" is the nature of which is located in the middle of the two kinds of nature of the extremities such as the nature of "brave" is between paranoid and lightness, "generous" is located between the greedy and wasteful, "just" which is located in between compassion and violence. 


\subsection{At-Tasamuh}

At-tasamuh (tolerant) became one of the basic attitude and character of Islamic teachings, so called Islam as a religion of compassion the basic principles or the relationship of Islam with non-Moslems $\mathrm{s}$ have been mentioned in a number of verses, including in surah Ali'Imron verse 159 as follows according to some mufassir, the verse down to the Prophet (blessing and peace be upon him), in relation to the battle of Uhud [16]. Previously he did not want out (for war), but the result of consultation with the friends of the majority of them want war, so he followed the results of this consultation. In short, at the battle, Islam troop was losing because the captain of the archers left the position because they wanted to take the booty of war. Even the Prophet (blessing peace be upon him) was wounded on the war. From the story of the defeat of the Moslems $\mathrm{s}$ in the battle of Uhud is an extraordinary attitude shown by the Messenger of Allah, he can still-holding the anger, absorbing disappointment and still be kind and gentle toward his friends, forgive them and still invite them for discussion. So, the verse above illustrates that soft attitude remains the guidelines for those around you even though they hate you.

\subsection{At-Ta'awun}

At-ta'awun or giving help is one of the social characters which is praised as universal Any nations anywhere admit it as a good attitude, so do any religious values as deeds of praise. The Qur'an also recommends ta'awun, such as in Al-Surah Maida, verse 2, as follows al-maroghy in his interpretation said: the commands to help in doing good and piety that includes the joints "hidayah ijtimaiyah" from the Qur'an, is an obligation for people to help each other in all things that provide benefits to human life, both individuals and groups in matters of religion and worldly, and all deeds piety can be used to face all mafsadah and dangers [16].

\subsection{At-Tawazun}

At-tawazun (harmony) is the attitude and orientation of life that taught Islam, so that man is not trapped in extremities in life, not merely pursue life ukhrawi by ignoring the earthly life or vice versa, the Qur'an charged, among others in Surat Al-Qasas 77 as follows some of the many scholars interpretation says that the verse is the advice of the Prophet Moses (blessing be upon him) Qarun, one of the followers of the Prophet Moses which was formerly very obedient but then became arrogant and ungrateful, after his soul turned into materialist, pursuing earthly satisfaction, his life experienced disharmony between the pursuit of customer satisfaction and disorientation happiness ukhrawi materials [16].

\subsection{Inclusive attitude}

The efforts losing exclusive Religious is considered as a roots of conflict with accompanied by an inclusive and egalitarian attitude to be able to find a meeting point (convergence) religions[17]-[19]. Inclusive to exclusive opponents become one general description in the implementation of religious values in society. They are, in fact, cannot be seen partially. Inclusive and exclusive must be seen as a whole. Because, there are some things that are required for the exclusive as monotheism and there are some things that his nature inclusive as convenient. Meanwhile, not a few religious people have exclusive view must be applied as a whole without giving opportunity inclusive value [20]. Inclusive attitude to radical action mitigation options, criminal act, and resorting anti-social on behalf of religion.

The roots of religious life conflict occur because of the unilaterally claim of truth. Things become complicated when there is no party that gives the attitude of openness and build 
communication. Inclusive attitude at this present time appears to be one alternative to respect differences proportionally to avoid the claim of truth and the claim of salvation[21].

Inclusive attitude is expected to be able to provide the crevice tool on social interaction so that people still able to be reconciled to each other [22]. So religious differences, tribes and races will no longer be the main trigger conflict in both horizontaly and vertical. The victims are needless due to the conflict of religion. Inclusive attitude is needed by students [23], [24] in order to face the global world where differences become a problem that should be settled peacefully not radically [25].

\section{Method}

The approach and the type of research into something that is important in research, because it will provide greater clarity and specification of the carried-out research. The present research use implemented qualitative approach. Qualitative approach is done to see in depth and reveal the meaning of the natural research subjects. The subject of this research about "The implementation of the Principles of Aswaja in forming the inclusive attitude on SMA SPI students Batu City, East Java, Indonesia".

Now the type of this research is the case study. Case study research is a qualitative approach that researcher explore real life, contemporary limited system (case) or a variety of limited system (various cases), through data collection details and deeply involving various information sources or source compound information (e.g., observation, interview, audiovisual materials, and documents and reports), and reported description of the case and the theme of the case [26]. This research will explore the experiences of lecturers and students in the contemporary limited system or the focus of one particular case such as the implementation of the principles of Aswaja on multifaith schools. Data collection techniques that are used in the present study are observation, interview, and documentation. This research has been conducted from 2016 to 2018.

More clearly seen from the aspect of the selection of the case as the research object, there are at least three kinds of case studies which is developed by the authors of the intrinsic qualitative case study, instrumental case study, and collective case study [27]. This research is classified on the intrinsic case study because it is done to understand better a particular case the implementation of the principles of Aswaja -on multifaith schools.

\section{Results and Discussion}

\subsection{Implementation of the Principles At ta'aruf in Upper Secondary Schools Selamat Pagi Indonesia}

As explained in the introduction that SMA SPI has a vision as a school that forming Indonesians who possess Pancasila soul, become superior, independent, have cultural identity, be aware to environment, and be able to compete in the Global Era. One of the meaning of the soul of Pancasila here is to have the attitude of willing to accept difference as in the motto of Bhinneka Tunggal Ika which means unity in diversity [28]-[30].

Students in SMA SPI consists of different tribes and even from the background of different religions. The doctrine to accept difference further strengthened with the placement 
of students and students in the hostel (hostel students separately). So, the intensity of interaction between the students, and the students in acceptance of the scope of ethnic and religious differences grows stronger.

The students have a lot of interaction that is not a little presents a problem for other students [31]. One example of this is when one of the students from non-Moslems s to cook the pig in the kitchen boarding schools. Of course, this is a problem because in the end all kitchen appliances, affected by unclean in the perspective of Moslems students, become a serious problem, but after approach all the teachers of the religion of Islam and the managers of institution, the problem is solved at last. It was decided to maintain the cleanliness from the unclean, and kitchen appliances Moslems s and non-Moslems s are put in the distinction in their placement.

From the above simple events, it can be deduced that the Moslems students ideally is to do ta'aruf with non-Moslems s students. At the same time, they get the real learning, not just as defined in the general learning process. After that, they also learn about alternative solutions to solve the problem. At the same time at-ta'aruf against living place or country or invest the soul of nationalism is also a part that cannot be separated. Even becomes important as conveyed that ودولة دين imaroh which means that Islam includes religion and state [32]. The concept of mini Indonesia becomes a part of including nationalism in the SMA SPI. Even though SMA students from the SPI have religious differences, tribe, and race ; they are still able to maintain the existence of SMA SPI until today.

\subsection{The implementation of the Principles At-Tawasuth in Upper Secondary Schools Selamat Pagi Indonesia}

The recruitment of students in school of SMA SPI has rigorous rules. First, the students must be from among is not capable of an orphan, or orphans. Second, the quota of religion embraced by students have been established which the number of students who are Moslem $40 \%$, the number of students who are Protestant Christian 20\%, the number of students of Christian Catholic 20\%, the number of students of Hindu $10 \%$, the number of students that Buddhist $10 \%$. The amount of percentage that is intended to create a mini Indonesia in the school environment of SMA SPI. The students were allowed to return to home only every six months. At the beginning of the establishment of the school of SMA SPI, With the background of multifaith students, the practice of religion scope, tend to be exclusive, still occurs. As the special attention that have tendency on certain religion, so that the conversion inter religions among students occurs. However, after the incident, all the management and teachers agreed to assign one of the rules for the students in SMA SPI to not allowed to move to the other religions. The implementation of At-tawasuth more visible after the regulation implemented. Indirectly, this rule gives lessons to the students that at the tawasuth or moderate to large capital to shows that Islam is a religion that is far from the values of radical.

\subsection{The implementation of the Principles At-tasamuh in Upper Secondary Schools Selamat Pagi Indonesia}

It is undeniable that there is still much debate in Indonesia related to the implementation of tolerance. Such as in particular, cases to say the Christmas holiday between the teachers to the other has different opinions. On the contrary, from the debate at-tasamuh attitude remains the main value. Although different, the people of Islam succeeded in mutual respect of each opinion [33]. No conflict appears which means despite the community have differences in the saying of welcome Christmas.

Tasamuh or being tolerant become an extraordinary experience and it appears in each 
student activities in SMA SPI [9]. Starting from the implementation of daily worship, they help one another to remind if there are who forget to perform acts of worship. In addition, the commemoration of the great day in every religion they do not feel disturbed by religious activities even though the places of worship of five religions are near. There are even students who are Moslem half memorized prayer Christians because of frequent heard. Even there is also the students non-Moslems s who feel calm when hearing the azan.

From the description above, tasamuh provides the implications of the perpetrators of tolerant itself. Further, it is implicated on abstained radical values in his life [34], the students will be synthesized in the spirit of religion that is given tolerance [35], [36]. In this case, the students must be able to maintain tolerance not to exceed the limit of tawhid or acts of worship that is believed. Because, if it is not able to give the supervisor on the value of tolerance, it can be so biased, and ultimately, the implementation of practice tolerance is misleading. As Moslems worship is done in the church by reason of tolerance, of course, it is prohibited. SMA SPI students is taught to always keep their beliefs exclusively and inclusive on the level of social interaction.

\subsection{The implementation of the Principles At-Ta'awun in Upper Secondary Schools Selamat Pagi Indonesia}

At the Ta'awun or helping each other becomes the daily routines in SMA SPI. As described in the introduction that SMA SPI student's do not charge for their education. To meet the operational costs of the SMA SPI students are guided to develop the soul of entrepreneurship [11]. There are many efforts that have been done such as the students create and market snacks or special snacks of Batu, students make theater shows, accompanying outbound for children of early age. Unconsciously, the value of at-ta'awun was realized on themselves when developing the soul entrepreneurs. The entrepreneurial activities in SMA SPI was conducted by the team, so that without realizing that they have practiced at ta'awun or helping each other.In addition, at-ta'awun become an integral part when the SMA SPI students commemorate religious day such as the feast of Christmas. Tasks for students non-Christians help the preparation of the event without following the religious ceremony. So, the students can only help the process of holding the great day of the feast of every religion. Without following the religious sacred efforts.

\subsection{The implementation of the Principles At-Tawazun in Upper Secondary Schools Selamat Pagi Indonesia}

The implementation of the principles at-tawazun felt upheld in SMA SPI. The rules that applied did not respect the tribe of religion, and all students must perform it unless they will get the punishment. The regulation of SMA SPI covers religious activities and regulations related to formal schools. As like the morning worship, having relationships and others.

In addition to the religious principles in meeting the needs of the school, SMA SPI implements entrepreneurs' activities integrated into the activities of the school. SMA SPI held three activities on the students, first teaching and learning activities held at the same time as other schools, which started from 07.00 am to $02.00 \mathrm{pm}$. Both the informal activities started from dawn in the form of students' religious activities' the three extracurricular activities packaged in the form of entrepreneurship. The entrepreneur activities include three containers of kampung Kids, kampung Teens, and kampung success (the form of training activities to be able to become entrepreneurs). In fulfilling worldly needs and ukhrowi at-tawazun (hereafter) become guidelines for the student activities at SMA SPI. At tawazun or harmony more appears on the SMA SPI students when they conduct worship and in accordance with the practiced 
religion in order to fulfill the spiritual needs, and in order to fulfill their physical needs, they do a lot of creativity that is packaged in the form of entrepreneurship. Creativity is needed not only in the arts [37], [38], but in fields such as entrepreneurship and learning [39], [40].

\section{Conclusion}

Explicitly, Aswaja principles such as at-ta'aruf, at-tawassuth, at-tasamuh, at-ta'awun, and at-tawazun was realized in SMA SPI. It was clearly seen from the school activity. The principles of Aswaja grows well in eclecticism schools. This indicates that the principles of Aswaja successfully face the challenges that influenced the differences of both religious and tribe differences. In addition, implicitly, if Aswaja principles can be applied in multifaith schools ,so it will indirectly rejects the spread of radical Islam. Inclusive attitude become the principles of Aswaja that has been applied in SMA SPI. On the other side, inclusive attitude makes the students calmer in facing the issues that influenced religious differences, tribe, and race. The practice to have competition in good to anyone without seeing the background of religion, tribe, and wealth will become the daily routines in SMA SPI. Thus, indirectly, the students of SMA SPI apply the principles of Aswaja in order to create a peaceful environment in the local scope and it is hoped to contribute to peace in the global.

\section{References}

[1] R. B. Sumarsono, A. Imron, B. B. Wiyono, and I. Arifin, "Parents ' Participation in Improving the Quality of Elementary School in the City of Malang, East Java , Indonesia," Int. Educ. Stud., vol. 9, no. 10, pp. 256-262, 2016.

[2] L. M. Padilla-walker, S. A. Hardy, and K. J. Christensen, "Adolescent Hope as a Mediator Between Connectedness and Adolescent Outcomes," J. Early Adolesc., vol. 31, no. 6, pp. $853-$ 879, 2011.

[3] X. U. Jiang, E. S. Huebner, K. J. Hills, and S. Carolina, "Parent Attachment and Early Adolescents' Life Satisfaction: the Mediating Effect of Hope," Psychol. Sch., vol. 50, no. 4, pp. 340-352, 2013.

[4] M. A. Lawson, "School-Family Relations in Context, Parent and Teacher Perceptions of Parent Involvement," Urban Educ., vol. 38, no. 1, pp. 77-133, 2003.

[5] J. Gibson and S. Olivia, "The Effect of Infrastructure Access and Quality on Non-Farm Enterprises in Rural Indonesia," World Dev., vol. 38, no. 5, pp. 717-726, 2010.

[6] F. R. Muhammad and M. Ashadi, "Behaviorism or Mentalism? the Case of Foreign Language Learning Process in Modern Islamic Boarding Schools," Int. J. Indones. Educ. Teach., vol. 3, no. 1, pp. 58-66, 2019.

[7] M. T. Hasan, Pendidikan Multikultural Sebagai Opsi Penanggulangan Radikalisme. Malang: UNISMA, 2016

[8] N. Hariyati, "Pengembangan Sekolah Berbasis Multikultural," J. Pendidik. Hum., vol. 2, no. 4, pp. 383-390, 2014.

[9] U. Sumbulah, "Kebebasan Beragama di SMU Selamat Pagi Indonesia Kota Batu Malang," AlTahrir, vol. 14, no. 2, pp. 363-384, 2014.

[10] P. R. N. Mianto, Sunaryanto, and S. U. M. Widjaja, "Internalisasi Nilai Kewirausahaan di Sekolah Menengah Atas," in National Conference On Economic Education, 2016, vol. 1, pp. 1241-1256.

[11] Suryaman, "Pendidikan Funecopreneur di Sekolah Menengah Atas," J. Entrep. dan Entrep., vol. 1, no. September, pp. 34-40, 2012. 
[12] A. M. Shofwan, "The Implementation of Islamic Multicultural Learning Value Through Aswaja and Nu (Case Study at MI Miftahul Huda Papungan 01 Blitar )," J. Dev. Res., vol. 1, no. May, pp. 15-23, 2017.

[13] Helmawati, "Implementasi Nilai-nilai Aawaja dalam Memperkokoh Karakter Bangsa dan Mewujudkan Entitas NKRI," Sipatahoenan South-East Asian J. Youth, Sport. Heal. Educ., vol. 4, no. April, pp. 51-68, 2018.

[14] Munawir, “Aswaja NU Center dan Perannya sebagai Benteng Aqidah,” Shahih, vol. 1, no. 1, pp. 61-81, 2016.

[15] M. Arif, "Revitalisasi Pendidikan Aswaja An Nahdliyah (Ke-Nu-An) dalam Menangkal Faham Radikalisme di Smk Al-Azhar Menganti Gresik,” J-PAI J. Pendidik. Agama Islam, vol. 5, no. 1, pp. 15-25, 2018.

[16] Al-Qur'an. Jakarta: Kementrian Agama RI, 2009.

[17] Sukidi, Teologi Inklusif Cak Nur. Jakarta: Penerbit Buku Kompas, 2001.

[18] E. Baldwin and M. Thune, "The Epistemological Limits of Experience-Based Exclusive Religious Belief," Relig. Stud., vol. 44, pp. 445-455, 2008.

[19] K. Greene and D. L. Rubin, "Effects of Gender Inclusive/Exclusive Language in Religious Discourse,” J. Lang. Soc. Psychol., vol. 10, no. 2, pp. 81-98, 1991.

[20] J. E. Terpstra and Æ. R. Tamura, "Effective Social Interaction Strategies for Inclusive Settings," no. December 2007, pp. 405-411, 2008.

[21] M. Sulistiono, "The Importance Of Multicultural Islamic Studies In Madrasah (Islamic School) To Develop Inclusive Attitude Of Students," in International Conference on "Islam Nusantara, National Integrity, and World Peace" 2018, 2018, pp. 223-232.

[22] A. T. Hashim, N. Insyiraah, A. Bakar, N. Mamat, and A. R. Razali, "Social Interactions among Multi-Ethnic Students Social Interactions among Multi-Ethnic Students," Asian Soc. Sci., vol. 12, no. 7, pp. 47-58, 2016.

[23] E. H. Mattson and A. M. Hansen, "Inclusive and Exclusive Education in Sweden: Principals' Opinions and Experiences," Eur. J. Spec. Needs Educ., vol. 24, no. 4, pp. 37-41, 2009.

[24] P. Haug and P. Haug, "Understanding Inclusive Education: Ideals and Reality," Scand. J. Disabil. Res., vol. 19, no. 3, pp. 206-217, 2017.

[25] M. Threlkeld, “'Chaos,War, or A New World Order?' A Radical Plan for Peace and World Goverment in the 1930S," Peace Chang., vol. 43, no. 4, pp. 473-497, 2018.

[26] Cresswell and J. W, Penelitian Kualitatif \& Desain Riset. Yogyakarta: Pustaka Pelajar, 2015.

[27] A. Salim, Teori \& Paradigma Penelitian Sosial. Yogyakarta: Tiara Wacana, 2006.

[28] M. I. Farisi, "Mohammad Imam Farisi Bhinneka Tunggal Ika (Unity in Diversity): from Dynastic Policy to Classroom Practice," J. Soc. Sci. Educ., vol. 13, no. 1, pp. 46-61, 2014.

[29] I. N. Pursika, "Kajian Analitik Terhadap Semboyan "Bhinneka Tunggal Ika "," J. Pendidik. dan Pengajaran, vol. 42, no. 1, pp. 15-20, 2009.

[30] G. Lestari, "Bhinneka Tunggal Ika: Khasanah Multikultural," J. Pendidik. Pancasila dan Kewarganegaraan, vol. 28, no. 1, pp. 31-37, 2015.

[31] D. W. Johnson, "Student-Student Interaction: The Neglected Variable In Education," Educ. Res., no. January, pp. 5-10, 1981.

[32] M. T. Hasan, Ahlussunnah Wal-Jama'ah dalam Persepsi dan Tradisi NU. Jakarta: Lantabora Press, 2003

[33] H. Wani, R. Abdullah, and L. W. Chang, "An Islamic Perspective in Managing Religious Diversity," religions, vol. 6, no. May, pp. 642-656, 2015.

[34] A. F. Rodli, E. Boeriswati, and M. A. Prasnowo, "Android-based games to detect history of radicalism," in Journal of Physics: Conference Series 1175, 2019, pp. 1-5.

[35] A. Furnham and J. Marks, "Tolerance of Ambiguity: A Review of the Recent Literature," Psychology, vol. 4, no. 9, pp. 717-728, 2013.

[36] W. Juwita, A. Salim, and W. Winarno, "Students ' Tolerance Behavior in Religious-Based Primary School : Gender Perspective,” Int. J. Educ. Res. Rev., vol. 3, no. 3, pp. 51-58, 2018.

[37] Z. Zakaria, P. Setyosari, S. Sulton, and D. Kuswandi, "The Effect of Art-Based Learning to Improve Teaching Effectiveness in Pre-Service Teachers," J. Educ. Gift. Young Sci., vol. 7, no. 
3, pp. 579-592, Sep. 2019.

[38] H. Arov, "Supporting Students' Key Competences In Visual Art Classes: The Benefits Of Planning," no. January, pp. 285-299, 2019.

[39] D. Y. Hamidi, K. Wennberg, and H. Berglund, "Creativity in Entrepreneurship Education Creativity in entrepreneurship education," J. Small Bus. Enterp. Dev., vol. 15, no. 2, pp. 304320, 2008.

[40] M.-M. Camacho-Miñano and C. del Campo, "The Role of Creativity in Entrepreneurship: An Empirical Study on Business Undergraduates," Educ. Train., vol. 59, no. 7/9, pp. 672-688, 2017. 